\title{
Associative diazotrophic bacteria in grass roots and soils from heavy metal contaminated sites
}

\author{
FÁTIMA M.S. MOREIRA ${ }^{1}$, ANDERSON LANGE ${ }^{2}$, OSMAR KLAUBERG-FILHO ${ }^{3}$, JOSÉ O. SIQUEIRA ${ }^{1}$, \\ RAFAELA S.A. NÓBREGA ${ }^{4}$ and ADRIANA S. LIMA ${ }^{4}$ \\ ${ }^{1}$ Departamento de Ciência do Solo (DCS), Universidade Federal de Lavras (UFLA), Caixa Postal 3037, 37200-000 Lavras, MG, Brasil \\ ${ }^{2}$ Departamento de Agronomia, UNEMAT, Rodovia MT 208, km 147, Jardim Tropical, 78580-000 Alta Floresta, MT, Brasil \\ ${ }^{3}$ Universidade do Estado de Santa Catarina (UDESC), Caixa Postal 281, 88520-000 Lages, SC, Brasil \\ ${ }^{4}$ Departamento de Ciência do Solo (DCS), Universidade Federal de Lavras (UFLA) \\ Programa de Pós-graduação em solos e nutrição de plantas, Caixa Postal 3037, 37200-000 Lavras, MG, Brasil
}

Manuscript received on August 29, 2006; accepted for publication on July 22, 2008;

contributed by JOSÉ O. SIQUEIRA*

\begin{abstract}
This work aimed to evaluate density of associative diazotrophic bacteria populations in soil and grass root samples from heavy metal contaminated sites, and to characterize isolates from these populations, both, phenotypically (Zinc, Cadmium and $\mathrm{NaCl}$ tolerance in vitro, and protein profiles) and genotypically (16S rDNA sequencing), as compared to type strains of known diazotrophic species. Densities were evaluated by using NFb, Fam and JNFb media, commonly used for enrichment cultures of diazotrophic bacteria. Bacterial densities found in soil and grass root samples from contaminated sites were similar to those reported for agricultural soils. Azospirillum spp. isolates from contaminated sites and type strains from non-contaminated sites varied substantially in their in vitro tolerance to $\mathrm{Zn}^{+2}$ and $\mathrm{Cd}^{+2}$, being $\mathrm{Cd}^{+2}$ more toxic than $\mathrm{Zn}^{+2}$. Among the most tolerant isolates (UFLA 1S, 1R, S181, S34 and S22), some (1R, S34 and S22) were more tolerant to heavy metals than rhizobia from tropical and temperate soils. The majority of the isolates tolerant to heavy metals were also tolerant to salt stress as indicated by their ability to grow in solid medium supplemented with $30 \mathrm{~g} \mathrm{~L}^{-1} \mathrm{NaCl}$. Five isolates exhibited high dissimilarity in protein profiles, and the 16S rDNA sequence analysis of two of them revealed new sequences for Azospirillum.
\end{abstract}

Key words: Azospirillum, Zinc, Cadmium, soil contaminants, Nitrogen-fixing bacteria.

\section{INTRODUCTION}

Mining and metallurgical industry play an important role in worldwide economy, particularly in Brazil. However, these industries can be responsible for environmental impacts caused mainly by heavy metal (HM) contamination of soil, vegetation and water bodies. Soil contamination with $\mathrm{HM}$ is a major constraint for plant growth (Marques et al. 2000) and for microbial density, diversity and processes, including biological Nitrogen fixation (Tyler 1981, Hirsch et al. 1993, Dias-Júnior et al. 1998, Giller et al. 1998, Klauberg-Filho et al. 2002).

\footnotetext{
* Member Academia Brasileira de Ciências

Correspondence to: Fátima Maria de Souza Moreira

E-mail: fmoreira@ufla.br
}

Biological Nitrogen fixation is mediated by several prokaryotic species occurring both in soil and rhizosphere, that can establish either symbiotic or associative relationships with a variety of plant species contributing to their N-nutrition. Among associative Nitrogen fixers, Azospirillum spp., Burkholderia and Herbaspirillum spp., are reported to occur in the ecto and endorhizosphere of grasses and in other monocotyledon species (Döbereiner 1978, Magalhães and Döbereiner 1984, Santos et al. 2001, Baldani and Baldani 2005). In spite of the great volume of information about these bacteria, their occurrence in HM contaminated soils and HM effects on associative Nitrogen fixers are scarce. Lorenz et al. (1992) and Dahlin et al. (1997) found reduced 
nitrogenase activity by heterotrophic soil bacterial populations in HM contaminated soil treated with sewage sludge. These authors also found high negative correlation between nitrogenase activity and $\mathrm{Zn}, \mathrm{Cd}$ and $\mathrm{Cu}$ concentrations in the soil. Hayat et al. (2002) found that asymbiotic Nitrogen fixer populations, in soil receiving oil refinery wastewater, tolerate $\mathrm{Ni}, \mathrm{Cd}, \mathrm{Pb}, \mathrm{Cu}$ and $\mathrm{Zn}$ tested individually, at concentrations up to $400 \mu \mathrm{g} \mathrm{mL}^{-1}$. In the only study with associative diazotrophic isolates (Strzelczyk et al. 1997), it was found a similar behavior of isolates to different $\mathrm{HM}(\mathrm{Zn}, \mathrm{Cd}$ and $\mathrm{Cu})$. However, results of these work are highly contradictory to what has been reported for other metal-bacteria interactions showing markedly differentiated response to distinct metals. The understanding of associative diazotroph behavior in HM contaminated soil may provide good insights for the ecology and application of these organisms in rehabilitation practices.

In this work we assessed associative diazotrophic bacterial population densities in heavy metals contaminated soils and grass roots. We also characterized, phenotypically (Zinc, Cadmium, and $\mathrm{NaCl}$ tolerance in vitro and protein profiles) and genotypically (16S rDNA sequencing) isolates from these sites in comparison to type strains.

\section{MATERIALS AND METHODS}

Studied Sites AND SAMPLING

Soil and grass root samples were collected in October (dry season) from five dumping sites near a Zinc processing industry (Companhia Mineira de Metais - CMM), located at Três Marias (MG). Zn and Cd were the main soil contaminants in all sites, as their contents were very high considering the allowed limits according to the European Communities (Table I). All these sites have the predominance of grass species such as: Brachiaria decumbens, B. brizantha, B. mutica and Andropogon sp. From each site, three samples of rhizosphere soil and three samples of roots were randomly collected at 0 $20 \mathrm{~cm}$ depth. The samples were placed in heat-isolated protective cases, and transferred to the laboratory where they were stored at $-4^{\circ} \mathrm{C}$ until used for analysis.

\section{BACTERIAL DENSITIES AND ISOLATION}

Densities of diazothophic species were assessed by the most probable number method obtained by the inocu- lation of successive decimal dilutions of samples (first dilution: $10 \mathrm{~g}$ root or soil/95 $\mathrm{mL}$ sterile $\mathrm{NaCl}$ solution $5.5 \mathrm{~g} \mathrm{~L}^{-1}$ ) in semi-solid media, known to favor growth of Azospirillum spp. (A. lipoferum, A. brasilense, A. amazonense) (Magalhães and Döbereiner 1984, Döbereiner et al. 1995) and Herbaspirillum spp. (H. seropedicae, H. rubrisubalbicans) (Döbereiner et al. 1995) as well as other diazotrophs (Nóbrega et al. 2004) such as Burkholderia spp. The following media were used: Fam (Magalhães and Döbereiner 1984), NFb and JNFb (Döbereiner et al. 1995). Media were distributed into $10 \mathrm{~mL}$ vials (4 mL medium/vial). From each sample dilution, $0.1 \mathrm{~mL}$ was inoculated in each medium with three replicates (vials). Positive cultures for growth of diazotrophs were indicated by pellicle formation near medium surface. Isolates were obtained from single colonies and identified according to procedures described by Magalhães and Döbereiner (1984) and Döbereiner et al. (1995).

\section{TyPe STRAins}

Type and reference strains of Azospirillum brasilense (BR $11001^{\mathrm{T}}$ ), A. lipoferum (BR $11080^{\mathrm{T}}$ ), A. amazonense (BR $\left.11140^{\mathrm{T}}\right)$, A. irakense $\left(\mathrm{KCB}^{\mathrm{T}}\right)$, Herbaspirillum seropedicae (BR $11175^{\mathrm{T}}$ ) and reference strain Burkholderia sp. (previously named B. brasilensis) (BR 11340), as well as reference strain BR 9004 identified as Burkholderia sp. (F.M.S. Moreira, unpublished results) were also included in the phenotypic assays for comparison with isolates from contaminated sites.

\section{INOCULUM}

Isolates and type strains were grown in liquid potato dextrose medium under $105 \mathrm{rpm}$ at $28^{\circ} \mathrm{C}$. After 10 days, one $\mathrm{mL}$ of each cell culture was submitted to centrifugation (Eppendorf centrifuge 5402, $14 \mathrm{rpm}, 5 \mathrm{~min}, 10^{\circ} \mathrm{C}$ ), discarding the supernatant and re-suspending cells in $1 \mathrm{~mL}$ saline solution $\left(\mathrm{NaCl} 5.5 \mathrm{~g} \mathrm{~L}^{-1}\right)$, respectively. This washing procedure was repeated three times to remove completely medium components from cell cultures that could cause a false positive growth in contaminated media. One $\mathrm{mL}$ of washed cells suspension in saline solution was transferred to modified solid media (potato dextrose) or to ten $\mathrm{mL}$ vials with the modified $\mathrm{N}$-free semi-solid media as described below. Treatments in all tests had three replicates. 
TABLE I

Heavy metal concentrations (Mehlich1) in soil samples from the various sites.

\begin{tabular}{l|c|c|c|c|c}
\hline \multirow{2}{*}{ Site/grass species } & \multicolumn{5}{|c}{ Heavy metal $\left.\left(\mathrm{mg}^{-1}\right)^{-1}\right)^{(1)}$ in soil } \\
\cline { 2 - 6 } & $\mathrm{Zn}$ & $\mathrm{Cd}$ & $\mathrm{Mn}$ & $\mathrm{Cu}$ & $\mathrm{Pb}$ \\
\hline $1-$ Brachiaria decumbens & 5739 & 67 & 267 & 4 & 30 \\
\hline $2-$ Andropogon $\mathrm{sp}$. & 5902 & 105 & 114 & 530 & 90 \\
\hline $3-$ B. decumbens & 12873 & 46 & 34 & 548 & 144 \\
\hline $4-$ B. mutica & 3960 & 223 & 76 & 215 & 134 \\
\hline $5-$ B. mutica & 15279 & 76 & 78 & 722 & 198 \\
\hline
\end{tabular}

(1) Permissible limits in European Communities: $\mathrm{Zn}=300 ; \mathrm{Cd}=3 ; \mathrm{Cu}=140$; $\mathrm{Pb}=300 \mathrm{mg} \cdot \mathrm{kg}^{-1}$ ("aqua regia" extracted).

TOLERANCE TO ZN, CD

Tolerance to $\mathrm{Zn}$ and $\mathrm{Cd}$ was assessed in potato dextrose agar and in semi-solid Nitrogen-free media (Fam, $\mathrm{NFb}$ ) in which diazotrophs grow acquiring atmospheric Nitrogen through nitrogenase activity. In both experiments, solid media and $\mathrm{N}$-free semi-solid media were modified by the addition of biological buffers HEPES (1.3 $\left.\mathrm{mg} \mathrm{L}^{-1}\right)$ and MES $\left(1.1 \mathrm{mg} \mathrm{L}^{-1}\right)$ and were supplemented with metals at concentrations ranging from 0 to $1,000 \mathrm{mg} \mathrm{Zn}^{+2} \mathrm{~L}^{-1}$ and from 0 to $54.1 \mathrm{mg} \mathrm{Cd}^{+2} \mathrm{~L}^{-1}$. Assayed concentrations were defined from results of the effects of these metals on tropical rhizobia isolates (Trannin et al. 2001a, Matsuda et al. 2002). Modified potato dextrose agar media was supplemented after autoclaving, with sterile solutions of $\mathrm{ZnSO}_{4} .7 \mathrm{H}_{2} \mathrm{O}$ and/ or $\mathrm{CdSO}_{4} .8 \mathrm{H}_{2} \mathrm{O}$ to give final desirable concentrations of $0 ; 125 ; 250 ; 500$ and $1,000 \mathrm{mg} \mathrm{Zn}^{2+} \mathrm{L}^{-1}$ or $0 ; 1.7 ; 3.4$; $6.8 ; 13.5 ; 27.1$ and $54.1 \mathrm{mg} \mathrm{Cd}^{2+} \mathrm{L}^{-1} . \mathrm{Zn}^{+2}$ and $\mathrm{Cd}^{+2}$ were tested separately or in combinations of different concentrations in potato dextrose medium. Metals combined in potato dextrose agar were only tested for A. amazonense. Fam and $\mathrm{NFb}$ semi-solid $\mathrm{N}$-free media were supplemented with sterile solutions of $\mathrm{ZnSO}_{4} .7 \mathrm{H}_{2} \mathrm{O}$ or $\mathrm{CdSO}_{4} .8 \mathrm{H}_{2} \mathrm{O}$ at the following concentrations of $\mathrm{Zn}^{2+}$ and $\mathrm{Cd}^{2+}: 0 ; 62.5 ; 125 ; 250 ; 500,1,000 \mathrm{mg} \mathrm{L}^{-1}$ and $0 ; 2.5 ; 5.0 ; 10.0 ; 20.0 ; 40.0,60.0 \mathrm{mg} \mathrm{L}^{-1}$, respectively. Media receiving $\mathrm{Zn}$ sulfate $\left(\mathrm{ZnSO}_{4} .7 \mathrm{H}_{2} \mathrm{O}\right)$ had the $\mathrm{pH}$ adjusted to 6.8 by addition of $\mathrm{KOH} 1 \mathrm{~N}$.

After the incubation period $\left(10\right.$ days at $\left.28^{\circ} \mathrm{C}\right)$, strains and isolates growth was assessed in modified solid medium by attributing scores as following:
$0=$ no visual growth, $1=$ very reduced growth, $2=$ low growth, 3 = intermediate growth, 4 = abundant growth, $5=$ very abundant growth as compared to the growth of the tested isolate/strain in the same medium without heavy metal supplementation. Maximum tolerated concentration (MTC) was determined as being the highest one with a growth score equal or higher than 1. Formation of typical pellicles near the surface was considered as positive growth in semi-solid modified N-free media (Magalhães and Döbereiner 1984, Döbereiner et al. 1995). Nitrogenase activity was measured by the acetylene reduction technique (Dilworth 1966) in all semi-solid media in four day old cultures by using a gas chromatograph Varian 3400-CX.

\section{TOLERANCE TO NACL}

In order to verify relationships between tolerance to different stresses, strains were also tested for $\mathrm{NaCl}$ tolerance. Potato dextrose agar medium was modified to obtain the following final $\mathrm{NaCl}$ concentrations: $0,10,20$, 30,50 and $80 \mathrm{~g} \mathrm{~L}^{-1}$, based on ranges commonly found in the literature (Tortora et al. 2000).

\section{TOTAL PROTEIN PROFILES}

Cultures were obtained as described previously for associative diazotrophs (Nóbrega et al. 2004). Wholecell protein extracts were prepared and sodium dodecylf sulfate polyacrylamide gel electrophoresis (SDSPAGE) performed by small modifications of the procedure of Laemmli (1970) as described by Kiredjian et al. (1986). The region in the protein profiles comprising the strongest thirteen bands was chosen and these 
were compared for similarity degree estimated by Jacard coefficient $(\mathrm{Sj})$, clustered by UPGMA method (average linkage clustering) (Everitt 1993) and graphically represent through a dendrogram, obtained by the program NTSYS-pc, version 2.0 t. (Rohlf 2002).

\section{ANALYSES OF 16S RDNA SEQUENCING}

Genomic DNA was obtained from potato medium log phase cultures of two isolates (UFLA1S and UFLAS181 - which were among the most tolerant to $\mathrm{NaCl}$ ) and extracted with Ultra-clean Soil DNA isolation kit from MOBIO laboratories. For $16 \mathrm{~S}$ rRNA sequencing, near full-length 16S rDNA genes were amplified with prime pair 8F (AGAGTTTGATCCTGGCTCAG) and 1492R (GGTTACCTTGTTACGACTT). PCR conditions were: 30 cycles of $94^{\circ} \mathrm{C} 40 \mathrm{~s} ; 55^{\circ} \mathrm{C} 40 \mathrm{~s} ; 72^{\circ} \mathrm{C} 90 \mathrm{~s}$. Directional partial sequencing of PCR-products was performed with $8 \mathrm{~F}$ primer. Purification of PCR products was performed with centrifugal filter devices Microcon Millipore. The isolates were sequenced at an ABI 3700 sequencer (Michigan State University). Sequences obtained were compared through BLAST software and submitted to the "National Center for Biotechnology Information" data base (http://www.ncbi.nlm.nih.gov/).

\section{RESULTS}

\section{BACTERIAL DENSITIES AND ISOLATES}

Bacterial growth varied markedly amongst samples. Densities found were higher in roots than in soil samples (Table II). Densities found in soil samples (log most probable number $\mathrm{g}^{-1}$ dry soil) by using Fam, NFb and JNFB were respectively in the ranges: 0.57 to $2.34,1.91$ to 4.34 and 0 to 2.72, whereas in root samples, the range of densities (log most probable numbers $\mathrm{g}^{-1}$ fresh root) were: 2.32 to $3.68,3.5$ to 5.63 and 2.27 to 5.5 . Seven isolates were obtained from soil (S) or root (R) samples inoculated in these media. Four of them had typical cultural characteristics of $A$. brasilense (UFLA 1R, S181, R214) or A. lipoferum (UFLA 1S) (Döbereiner et al. 1995) and three were similar to A. amazonense (UFLA R204, S34, S22) (Magalhães and Döbereiner 1984).

TOLERANCE TO ZN, CD

Maximum tolerated concentrations (MTC) of $\mathrm{Zn}^{+2}$ and $\mathrm{Cd}^{+2}$ in potato dextrose media varied among species and isolates (Figs. 1 and 2). Only A. amazonense isolates UFLA S34 and UFLA S22 and A. brasilense isolate UFLA $1 \mathrm{R}$ had MTC of $1,000 \mathrm{mg} \mathrm{Zn}^{+2} \mathrm{~L}^{-1}$. They had growth score equal to 2 (UFLA S34 and S22) or 4 (UFLA 1R) at this concentration (Fig. 1). Considering that $1,000 \mathrm{mg} \mathrm{L}^{-1} \mathrm{Zn}^{+2}$ was the highest concentration tested, perhaps these isolates could tolerate concentrations higher than that. No strain or isolate grew at $54.1 \mathrm{mg} \mathrm{Cd}^{+2} \mathrm{~L}^{-1}$. All isolates and strains tested in this study had MTC of $\mathrm{Cd}^{+2}$ equal to $27.1 \mathrm{mg} \mathrm{L}^{-1}$ (Fig. 2). However isolates UFLA S34, UFLA S22 and UFLA $1 \mathrm{R}$, which were more tolerant to $\mathrm{Zn}^{+2}$, had the highest growth score (4) at this concentration while the others had a growth score of 3 (UFLA 1S), 2 (UFLA R204, UFLA S181) or 1 (type strains and UFLA R214). $A$. amazonense did not grow at $\mathrm{Zn}^{+2}$ concentration of $500 \mathrm{mg} \mathrm{L}^{-1}$ in the presence of different concentrations of $\mathrm{Cd}^{+2}$ (Fig. 3). When $\mathrm{Zn}^{+2}$ concentrations were raised at fixed $\mathrm{Cd}^{+2}$ concentrations growth was depressed and the MTCs of $\mathrm{Zn}^{+2}$ were lower than when it was tested separately, indicating an additive toxic effect of these metals for A. amazonense. However, at fixed $\mathrm{Zn}^{+2}$ concentrations of 62.5 and $125 \mathrm{mg} \mathrm{L}^{-1}$ increasing the $\mathrm{Cd}^{+2}$ concentration did not affect or had little effect on growth score of UFLA S34 and UFLA S22 indicating antagonism of $\mathrm{Zn}^{+2}$ to $\mathrm{Cd}^{+2}$ at these combinations of concentrations. Time required for appearance of isolated colonies was delayed and colony size decreased with increasing concentrations of combined metals (Fig. 4). Also, it was observed that color of $A$. amazonense colonies shifted from white to yellowish under high $\mathrm{Zn}^{+2}$ and $\mathrm{Cd}^{+2}$ concentrations. However, the white color was recovered when colonies grown in high heavy metal concentration medium were replicated to metal free medium, indicating a metal induced response.

The most tolerant $A$. amazonense isolates (UFLA $\mathrm{S} 34, \mathrm{~S} 22$ ) to $\mathrm{Zn}^{+2}$ and $\mathrm{Cd}^{+2}$ growing at combined $\mathrm{N}$ (potato dextrose media) were also the most tolerant in Nitrogen-fixing conditions ( $\mathrm{N}$-free semi-solid media), but in this medium, BR $11140^{\mathrm{T}}$ exhibited the same tolerance of isolates belonging to this species. Tolerance to $\mathrm{Zn}^{+2}$ of $A$. amazonense strains/isolates in $\mathrm{N}_{2}$ fixing conditions decreased in relation to growth with combined Nitrogen, i.e., all of them had lower MTCs in N-free media (Table III) than in solid media (Figs. 1b, 2b). 
TABLE II

Density (log most probable number $\mathrm{g}^{-1}$ dry soil or fresh roots) of diazotrophic bacteria grown in media: Fam, NFb and JNFB in soil and roots samples collected at different sites of a dumping site of zinc industry.

\begin{tabular}{c|c|c|c|c|c|c}
\hline \multirow{2}{*}{ Site } & \multicolumn{3}{|c|}{ Soil } & \multicolumn{3}{c}{ Roots } \\
\cline { 2 - 7 } & Fam & NFb & JNFB & Fam & NFb & JNFB \\
\hline 1 & $2.34 \pm 2.03^{1}$ & $2.50 \pm 2.28$ & $2.72 \pm 2.39$ & $3.12 \pm 2.72$ & $3.5 \pm 1.9$ & $4.6 \pm 0.7$ \\
\hline 2 & $1.03 \pm 1.78$ & $4.34 \pm 1.57$ & $2.17 \pm 1.88$ & $3.68 \pm 1.34$ & $5.63 \pm 0.89$ & $5.5 \pm 2.3$ \\
\hline 3 & $1.31 \pm 1.14$ & $1.30 \pm 1.22$ & 0 & $2.32 \pm 2.24$ & $5.31 \pm 0.73$ & $4.86 \pm 0.86$ \\
\hline 4 & $1.02 \pm 0.1$ & $2.59 \pm 1.15$ & $2.10 \pm 1.87$ & $3.04 \pm 0.97$ & $5.14 \pm 0.53$ & $2.27 \pm 1.98$ \\
\hline 5 & $0.57 \pm 0.98$ & $1.91 \pm 1.66$ & $1.0 \pm 1.73$ & $2.81 \pm 2.44$ & $4.03 \pm 0.82$ & $4.44 \pm 0.65$ \\
\hline
\end{tabular}

${ }^{1}$ mean standard deviation.

(a)

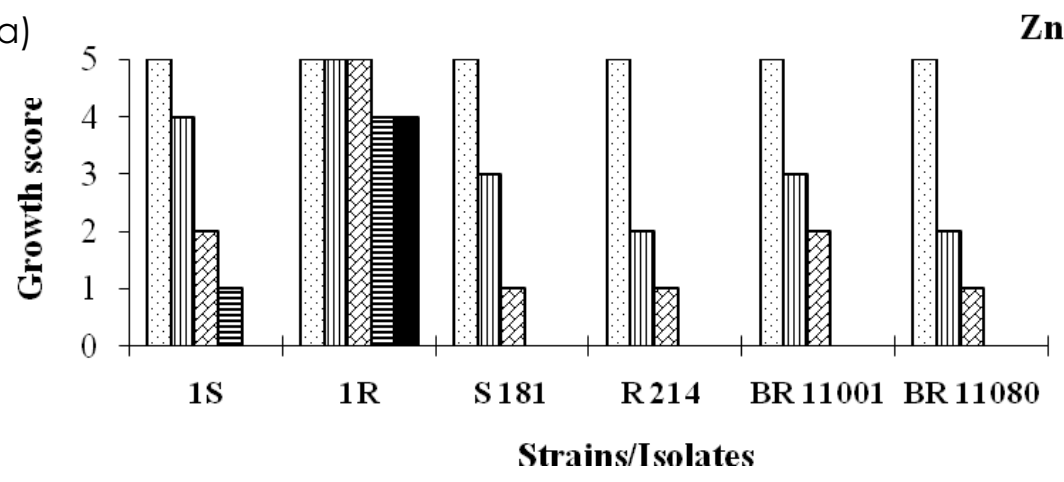

(b)
$\operatorname{Zn}\left(\mathbf{m g ~ \mathbf { L } ^ { - 1 } )}\right.$

$\square 0$

$\mathbf{\square} 125$

Q250

目 500

$\mathbf{\square} 1000$

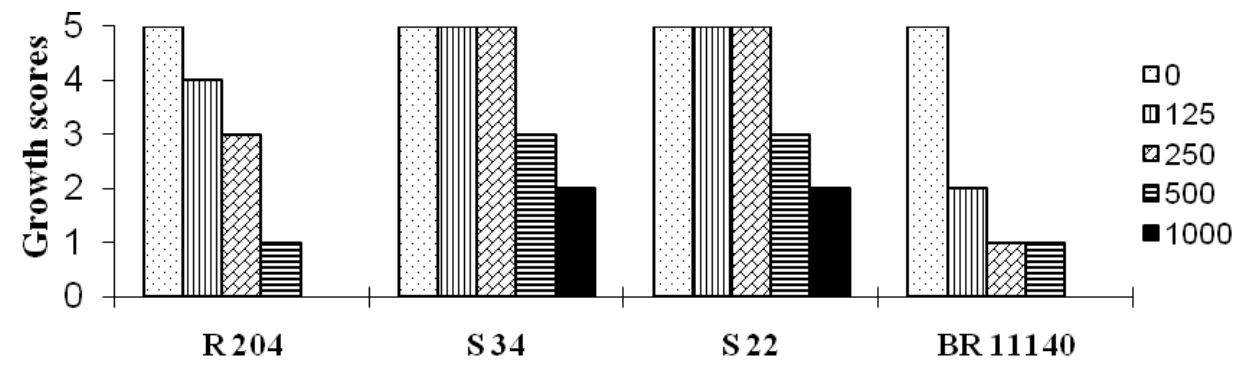

Strains/I solates

Fig. 1 - Growth scores of associative diazotrophic bacteria isolated from heavy metal contaminated area and type strains in potato dextrose agar medium supplemented with different concentrations of $\mathrm{Zn}^{2+}\left(\mathrm{mg} \mathrm{L}^{-1}\right)$ ten days after inoculation. a) Azospirillum lipoferum $\left(1 \mathrm{~S}\right.$ and $\left.\mathrm{BR} 11080^{\mathrm{T}}\right)$ and $A$. brasilense, $\left(1 \mathrm{R}, \mathrm{S} 181, \mathrm{R} 214, \mathrm{BR} 11001^{\mathrm{T}}\right)$; b) A. amazonense $\left(\mathrm{R} 204, \mathrm{~S} 34, \mathrm{~S} 22, \mathrm{BR} 11140^{\mathrm{T}}\right) .0=$ no visual growth, $1=$ very reduced growth, 2 = low growth, 3 = intermediate growth, 4 = abundant growth, $5=$ very abundant growth as compared to the growth of the strain/isolate in the same medium without heavy metal supplementation. 


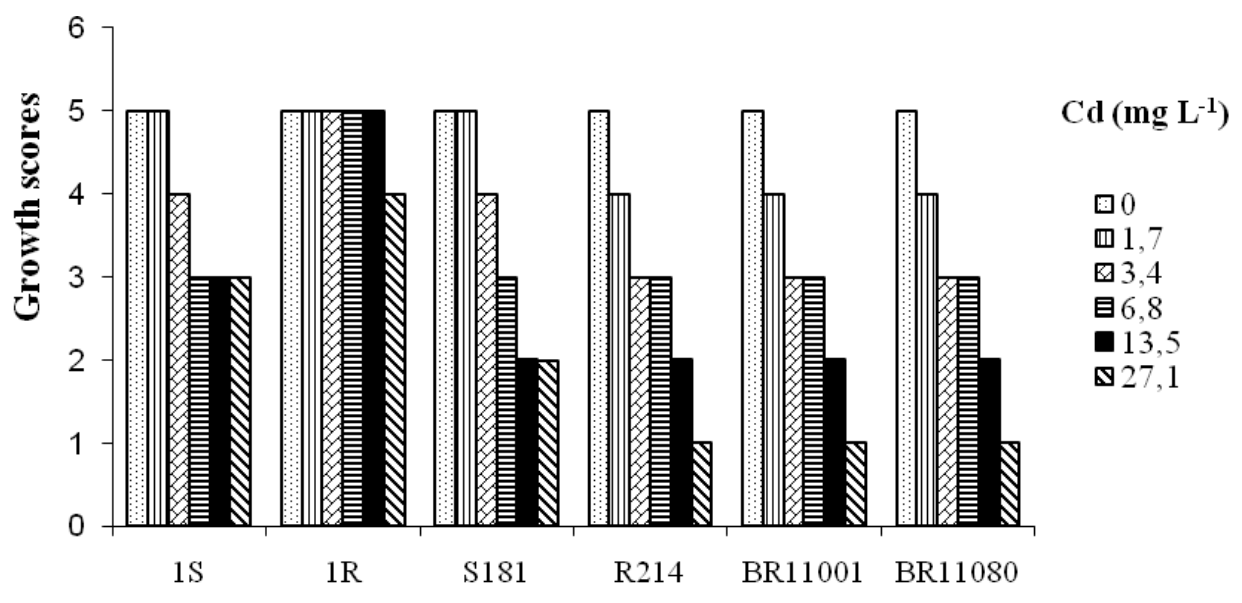

Strains/Isolates

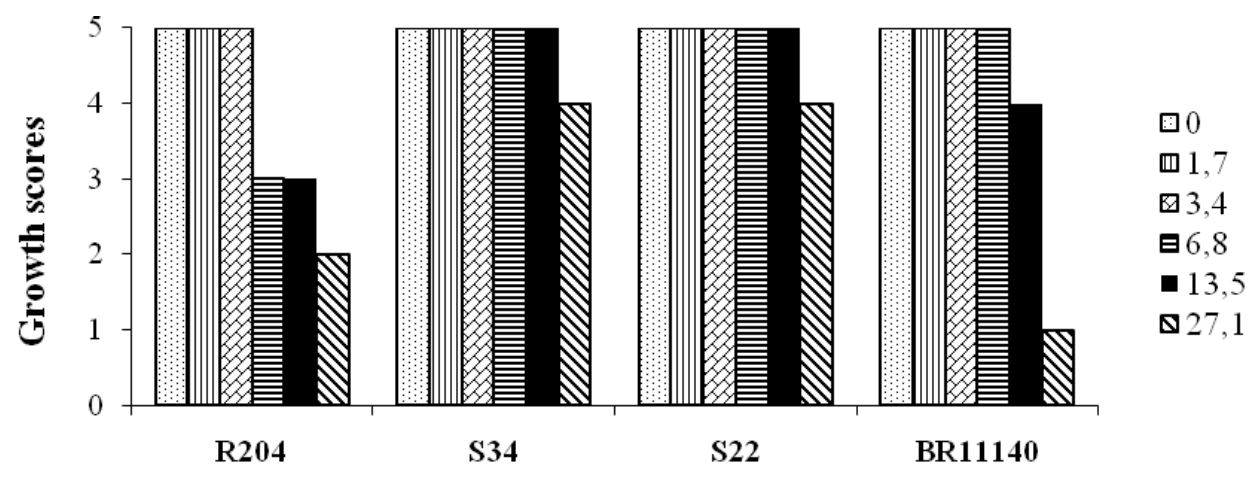

Strains/Isolates

Fig. 2 - Growth scores of associative diazotrophic bacteria isolated from heavy metal contaminated area and type strains in potato dextrose agar medium supplemented with different concentrations of $\mathrm{Cd}^{2+}\left(\mathrm{mg} \mathrm{L}^{-1}\right)$ ten days after inoculation. a) Azospirillum lipoferum $\left(1 \mathrm{~S}\right.$ and $\left.\mathrm{BR} 11080^{\mathrm{T}}\right)$ and A. brasilense (1R, S181, R214, BR $\left.11001^{\mathrm{T}}\right)$; b) A. amazonense (R204, S34, S22, BR11140 $) .0=$ no visual growth, $1=$ very reduced growth, 2 = low growth, 3 = intermediate growth, 4 = abundant growth, 5 = very abundant growth as compared to the growth of the strain/isolate in the same medium without heavy metal supplementation.

However, except for isolate UFLA 1R, A. brasilensel A.lipoferum behaved in a different way to $A$. amazonense, i.e, they tolerated the same or higher $\mathrm{Zn}^{+2}$ concentrations under $\mathrm{N}_{2}$ fixing conditions than with combined Nitrogen (Table III, Figs. 1a and 2a). Strain BR $11001^{\mathrm{T}}$ had the lowest MTC under $\mathrm{N}_{2}$ fixing conditions (Table III) as compared to media with combined Nitrogen (Figs. 1a and 2a). Nitrogenase activity decreased as metal concentrations increased, but it varied depending on both metal concentration and isolates/strains. In general, at the highest $\mathrm{Zn}^{+2}$ concentrations growth was delayed as shown by no acetylene reduction and absence of pellicles after four days at concentrations where growth were observed only after 10 days (Table III). Isolate UFLA $1 \mathrm{~S}$ was the only one found to tolerate the highest $\mathrm{Cd}^{+2}$ concentrations. Growth was delayed as indicated by acetylene reduction activity or pellicle presence after 4 days at the highest $\mathrm{Cd}^{+2}$ concentrations, i.e, the same behavior as in the media with $\mathrm{Zn}^{+2}$. Although, nitrogenase activity for $A$. amazonense decreased with increasing metal concentrations there was, in general, a slight increase for $A$. brasilense. 


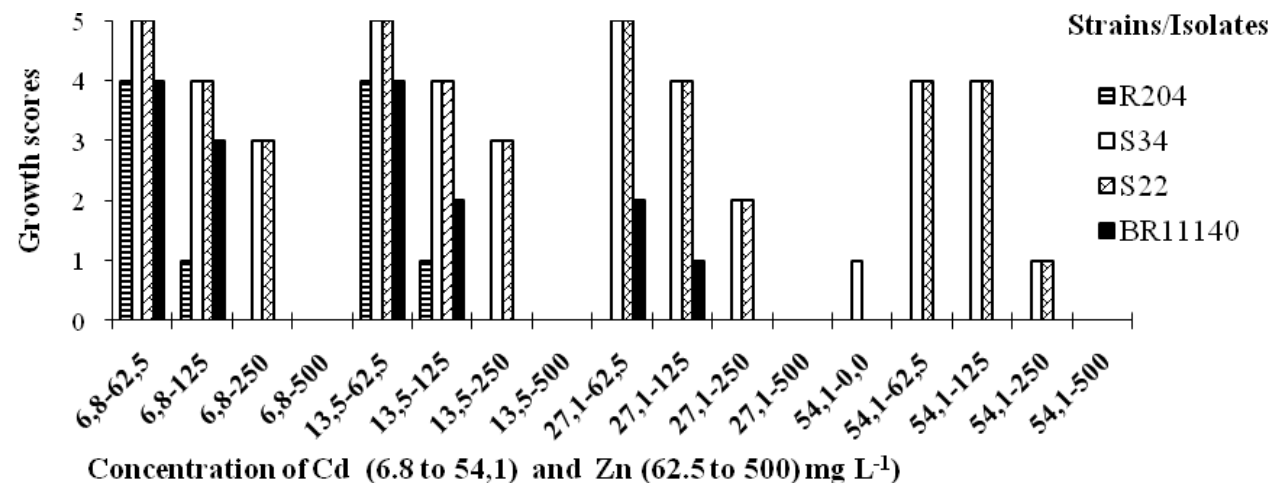

Fig. 3 - Growth scores of Azospirillum amazonense type strain $\left(B R 11140^{\mathrm{T}}\right)$ and isolates (R204, S34, S22) from heavy metal contaminated area in potato dextrose agar medium supplemented with different concentrations of $\mathrm{Cd}^{2+}+\mathrm{Zn}^{2+}\left(\mathrm{mg} \mathrm{L}^{-1}\right)$ ten days after inoculation. $0=$ no visual growth, 1 = very reduced growth, 2 = low growth, $3=$ intermediate growth, $4=$ abundant growth, $5=$ very abundant growth as compared to the growth of the strain/isolate in the same medium without heavy metal supplementation.

\section{TOLERANCE TO NACL}

No type strain or isolate was able to grow in medium containing $80 \mathrm{~g} \mathrm{~L}^{-1} \mathrm{NaCl}$. The type strain BR $11140^{\mathrm{T}}$ grew only in media supplemented with $10 \mathrm{~g} \mathrm{~L}^{-1} \mathrm{NaCl}$ or lower, therefore it was considered the most sensitive to saline stress. BR $11080^{\mathrm{T}}$, BR $11340^{\mathrm{T}}$, BR 9004 (Burkholderia sp.), UFLA R214, R204 and S34 tolerated up to $20 \mathrm{~g} \mathrm{~L}^{-1}$ of $\mathrm{NaCl}$, and they were classified as facultative halophytes. UFLA 1S, 1R, S181 and S22, BR $11175^{\mathrm{T}}$ and BR $11001^{\mathrm{T}}$ grew in up to $30 \mathrm{~g} \mathrm{~L}^{-1} \mathrm{NaCl}$, and Azospirillum irakense $\left(\mathrm{KBCl}^{\mathrm{T}}\right)$ grew in medium with $50 \mathrm{~g} \mathrm{~L}^{-1} \mathrm{NaCl}$, so they were considered tolerant to saline stress.

\section{Total Protein Profiles}

The protein profiles of isolates UFLA 1R and R204 were not revealed in the polyacrylamide gel. Figure 5 shows that no isolate was clustered with any type or reference strain of described species at similarity levels equal or above $75 \%$. Strains belonging to genus Azospirillum clustered together with type strains of these species at similarity levels of $43 \%$ (UFLA S181, 1S) and 50\% (UFLAS22), except for UFLA R214 that clustered with H. seropedicae (56\% and UFLA S34 (30\%), clustered with all the other strains.

\section{ANALYSES OF 16S RDNA SEQUENCING}

Comparison with the NCBI database (accessed August, $17^{\text {th }} 2006$ ) revealed UFLA IS sequence was more closely related to Azospirilum sp. WAI-19 and DA2-3-1
(96\%, corresponding to 251 of 259 bases) followed by A. lipoferum strain B2 (95\%, corresponding to 248 of 259 bases) and UFLAS181 sequence was more closely related to Azospirilum brasilense strain MTCC4036 (98\%, corresponding to 715 of 729 bases). Sequences were submitted to NCBI database and received accession numbers: DQ977745 (UFLA 1S) and DQ978776 (UFLA S181).

\section{DISCUSSION}

All the three semi-solid media tested were efficient to detect the presence of diazotrophs in the studied soils and roots samples from HM contaminated sites. Diazotrophic bacteria densities were, in general, higher in root than soil samples. Considering that JNFB medium is reported to favor growth of Herbaspirillum spp. (Döbereiner et al. 1995), it could be inferred that these organisms occurred in high numbers both in soil and root samples. However, these findings are not in accordance with the fact that Herbaspirillum spp. are obligate endophytic organisms and therefore rarely occurring in soil (Baldani and Baldani 2005). However, Nóbrega et al. (2004) pointed out that JNFb medium also detects species other than Herbaspirillum spp. such as Azospirillum spp., which was probably the case in the present study. In a previous study with soil samples from this area, Dias-Júnior et al. (1998) found no Azospirillum spp. This may be related to metal availability as affected by seasonality and rainfall. In addition, lack of a rhi- 

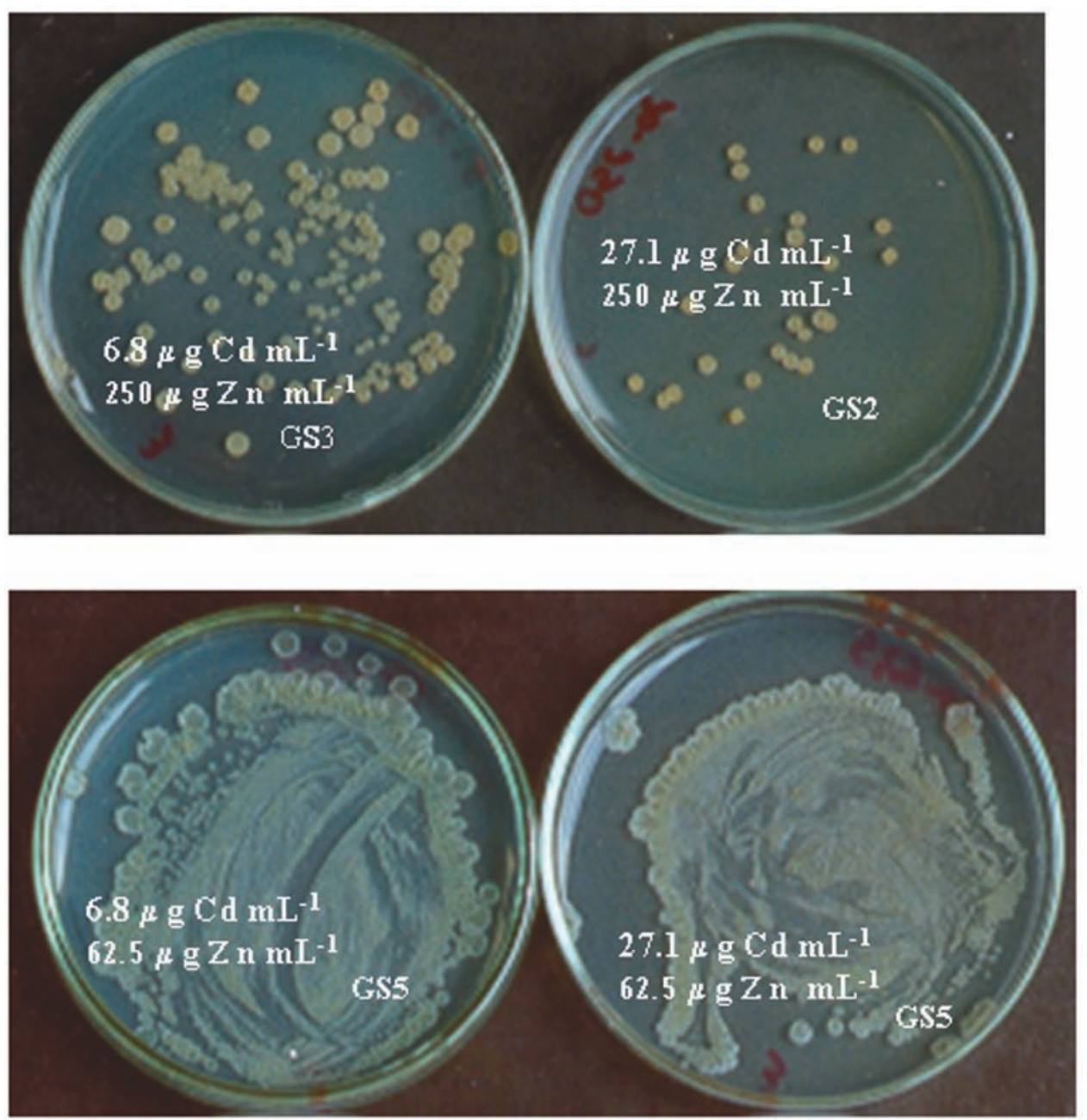

Fig. 4 - Growth scores (GS) of UFLA S34 at different combinations of $\mathrm{Zn}^{+2}$ and $\mathrm{Cd}^{+2}$ concentrations supplemented in dextrose agar medium. Figure shows colony color changing from white to yellow as well as growth decreasing with increasing concentrations of heavy metals. All plates received the some numbers of cells as inoculum. 2 = low growth, 3 = intermediate growth, 5 = very abundant growth as compared to the growth of the isolate in the same medium without heavy metal supplementation.

zosphere effect in soil samples might also have had a negative influence on diazotroph densities. The occurrence of diazotrophs in relatively higher densities in roots than in soil samples is probably due to a protective and stimulant microenvironment in roots, as suggested for acidity stress on Azospirillum spp. (Döbereiner 1978). Density values found in the present study were similar to the range found in several reports for non-contaminated agricultural soils (Magalhães et al. 1979, Baldani and Döbereiner 1980, Magalhães and Döbereiner 1984) thus indicating adaptation of this bacterial group to the excess of heavy metal.
The Azospirillum spp. isolates from contaminated soil exhibited higher tolerance to $\mathrm{Zn}^{+2}$ and $\mathrm{Cd}^{+2}$ than type strains from non-contaminated soils. This finding corroborates results for rhizobia isolates from the same area (Trannin et al. 2001a), when these were compared to isolates from non-contaminated soils. Tolerance of these diazotrophic isolates as compared to rhizobia from other studies (Angle et al. 1993, Matsuda et al. 2002) suggest a better adaptation of associative bacteria to the excess of heavy metals in soil. Matsuda et al. (2002) have shown 60 tropical rhizobia strains tolerance, ranging from 30 to $60 \mathrm{mg} \mathrm{L}^{-1} \mathrm{Cd}^{+2}$ and from 500 to 
TABLE III

Nitrogenase activity (acetylene reduction: nmoles ethylene/culture/hour) measured four days after inoculation by Azospirillum spp. cultures and Maximum Tolerated concentration (MTC) for growth measured by pellicle formation ten days after inoculation in media supplemented with increasing concentrations of $\mathrm{Zn}^{+2}\left(\mathrm{Zn} \mathrm{SO}_{4} .7 \mathrm{H}_{2} \mathrm{O}\right)$ or with $\mathrm{Cd}^{+2}\left(\mathrm{Cd} \mathrm{SO}_{4} .8 \mathrm{H}_{2} \mathrm{O}\right)$.

\begin{tabular}{|c|c|c|c|c|c|c|c|c|}
\hline \multirow[t]{2}{*}{ Strains/Isolates } & \multicolumn{7}{|c|}{$\begin{array}{c}\text { Nitrogenase activity } \\
\mathrm{Zn}^{+2} \text { concentration }\left(\mathrm{mg} \mathrm{L}^{-1}\right)\end{array}$} & \multirow[t]{2}{*}{$\begin{array}{c}\text { MTC } \\
\left(\mathrm{mg} \mathrm{L}^{-1}\right)\end{array}$} \\
\hline & 0 & 62.5 & 125 & 250 & 500 & \multicolumn{2}{|c|}{1000} & \\
\hline UFLA R204 & 63 & 25 & 3 & 0 & 0 & \multicolumn{2}{|c|}{0} & 125 \\
\hline UFLA S34 & 36 & 50 & 6 & 0 & 0 & \multicolumn{2}{|c|}{0} & 250 \\
\hline UFLA S22 & 83 & 65 & 27 & 0 & 0 & \multicolumn{2}{|c|}{0} & 250 \\
\hline BR $11140^{\mathrm{T}(1)}$ & 57 & 70 & 50 & 0 & 0 & \multicolumn{2}{|c|}{0} & 250 \\
\hline UFLA S181 & 168 & 8 & 23 & 11 & 0 & \multicolumn{2}{|c|}{0} & 500 \\
\hline UFLA R214 & 2 & 0 & 0 & 0 & 0 & \multicolumn{2}{|c|}{0} & 500 \\
\hline UFLA 1R & 45 & 6 & 11 & 0 & 0 & \multicolumn{2}{|c|}{0} & 500 \\
\hline UFLA $1 \mathrm{~S}$ & 18 & 11 & 0 & 0 & 0 & \multicolumn{2}{|c|}{0} & 500 \\
\hline \multirow[t]{3}{*}{ BR $11001^{\mathrm{T}(2)}$} & 13 & 0 & 0 & 0 & 0 & \multicolumn{2}{|c|}{0} & 250 \\
\hline & \multicolumn{8}{|c|}{$\mathrm{Cd}^{+2}$ concentration $\left(\mathrm{mg} \mathrm{L}^{-1}\right)$} \\
\hline & 0 & 2.5 & 5.0 & 10.0 & 20.0 & 40.0 & 60.0 & \\
\hline UFLA R204 & 25 & 20 & 4 & 1 & 0 & 0 & 0 & 40 \\
\hline UFLA S34 & 41 & 49 & 6 & 0 & 0 & 0 & 0 & 40 \\
\hline UFLA S22 & 41 & 49 & 6 & 0 & 0 & 0 & 0 & 20 \\
\hline BR $11140^{\mathrm{T}}$ & 67 & 3 & 1 & 0 & 0 & 0 & 0 & 20 \\
\hline UFLA S181 & 5 & 3 & 9 & 11 & 12 & 0 & 0 & 20 \\
\hline UFLA R214 & 66 & 0 & 0 & 0 & 0 & 0 & 0 & 40 \\
\hline UFLA 1R & 8 & 9 & 12 & 10 & 12 & 0 & 0 & 40 \\
\hline UFLA $1 \mathrm{~S}$ & 8 & 9 & 10 & 9 & 10 & 0 & 0 & 60 \\
\hline BR $11001^{\mathrm{T}}$ & 18 & 20 & 32 & 28 & 24 & 0 & 0 & 20 \\
\hline
\end{tabular}

Type strains of (1) A. amazonense and (2) A. brasilense.

$800 \mathrm{mg} \mathrm{L}^{-1} \mathrm{Zn}^{+2}$. Angle et al. (1993) found tolerances of rhizobia isolates from temperate regions only up to $2.5 \mathrm{mg} \mathrm{L}^{-1} \mathrm{Cd}^{+2}$ and $500 \mathrm{mg} \mathrm{L}^{-1} \mathrm{Zn}^{+2}$. Associative diazotrophic isolates in our study tolerated up to $1.000 \mathrm{mg}$ $\mathrm{L}^{-1} \mathrm{Zn}^{+2}$ and $60 \mathrm{mg} \mathrm{L}^{-1} \mathrm{Cd}^{+2}$.

Isolates UFLA S34 and UFLA S22 grew poorly or did not grow when $54.1 \mathrm{mg} \mathrm{L}^{-1} \mathrm{Cd}^{+2}$ was tested alone, but grew when this concentration was tested in combination with 62.5 or $125 \mathrm{~m} \mathrm{~L}^{-1} \mathrm{Zn}^{+2}$. This may be explained by antagonistic effects between these metals, as was reported for ectomycorrhizal fungi (Colpaert and Assche 1992). These authors found that increasing $\mathrm{Zn}^{+2}$ concentrations resulted in a reduction of the toxic effect of
$\mathrm{Cd}^{+2}$. It was found that only isolates UFLA S34 and UFLA S22 tolerated the highest concentrations of combined $\mathrm{Zn}^{+2}$ and $\mathrm{Cd}^{+2}$, which indicated that these isolates can be promising for plant inoculation in phytoremediation programs in multi-contaminated areas.

Yellow pigmentation associated with HM contamination occurred in a different way of previous reports. The dark pigment production by $A$. brasilense type strain in minimum culture medium with $2 \mathrm{mM} \mathrm{Zn}^{+2}$ (130.8 $\mathrm{mg} \mathrm{L}^{-1}$ ) reported by Gowri and Srivastava (1996) was not observed in the culture media used in our experiments (modified dextrose potato agar, Fam and $\mathrm{NFb}$ ). However, in another experiment (A. Lange et al., unpub- 

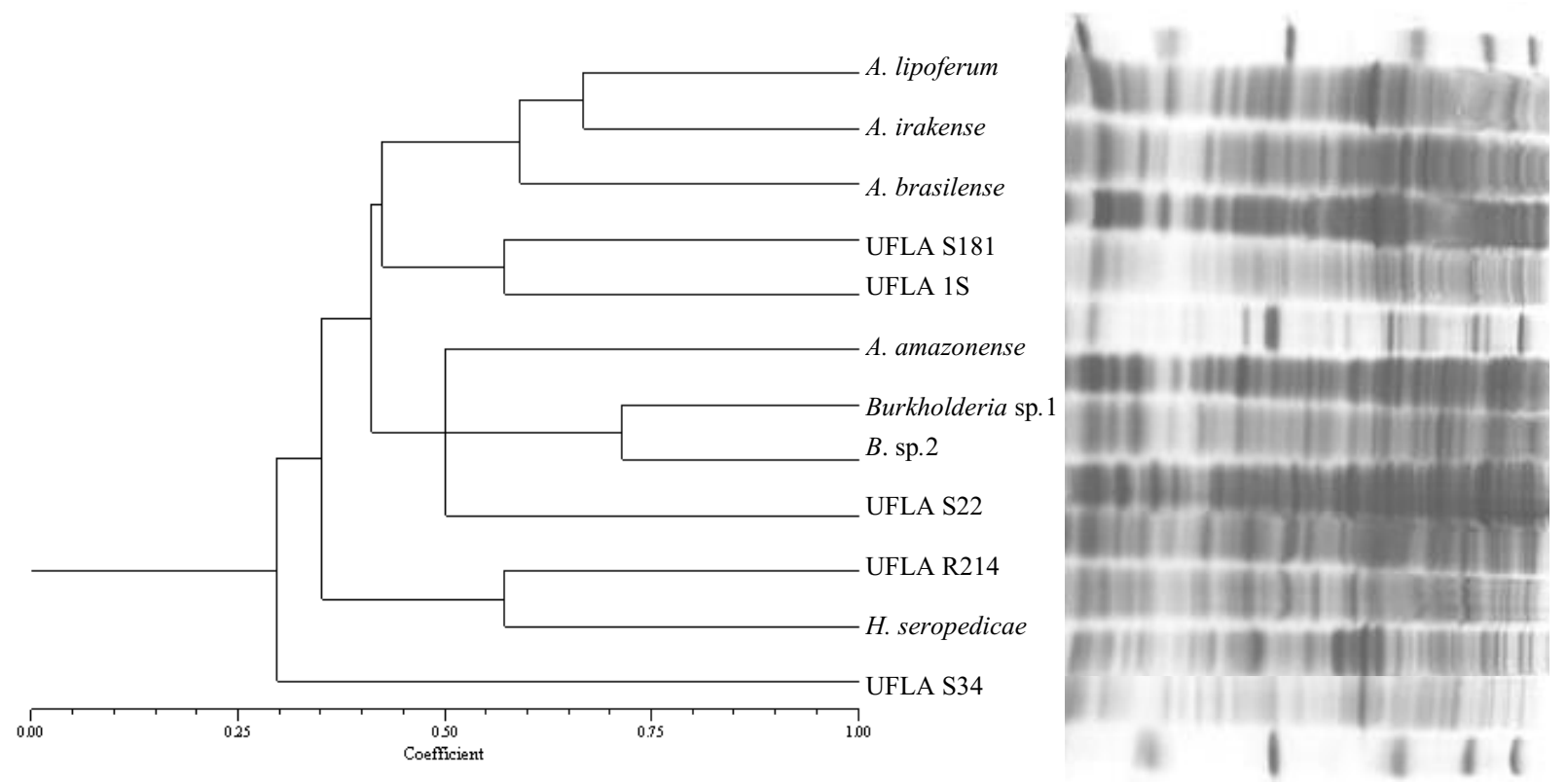

Fig. 5 - Dendrogram and total protein profiles of associative diazotrofics bacteria: MWM (molecular weight marker), A. lipoferum $\left(\mathrm{BR} 11080^{\mathrm{T}}\right)$, A. irakense $\left(\mathrm{KCB}^{\mathrm{T}}\right)$, A. brasilense $\left(\mathrm{BR} 11001^{\mathrm{T}}\right)$, UFLA S181, UFLA 1S, A. amazonense (BR11040 $\left.{ }^{\mathrm{T}}\right)$, Burkholderia sp.1 (BR 9004$)$, B. sp.2 (BR11340), UFLA S22, UFLA R214, H. seropedicae, $\left(B R 11175^{\mathrm{T}}\right)$, UFLA S34 e MWM.

lished results) it was found that pellets from centrifuged cultures of $A$. brasilense type strain and isolates grown in dextrose potato liquid medium, supplemented with 125 and $250 \mathrm{mg} \mathrm{Zn}^{+2} \mathrm{~L}^{-1}$, were darker than pellets from cultures grown in medium without metal amendment.

Studies regarding tolerance of associative diazotrophs to heavy metals have been widely neglected. Strzelczyk et al. (1997) found variation of three Azospirillum isolates concerning their tolerance to $\mathrm{Zn}^{+2}, \mathrm{Cd}^{+2}$ and $\mathrm{Cu}^{+2}$. They also found similar tolerance to each one of the three metals at concentrations ranging from 1 to $100 \mathrm{mg} \mathrm{L}^{-1}$, and at $500 \mathrm{mg} \mathrm{L}^{-1}$ growth was completely inhibited. Although we also found variation in tolerance of strains/isolates to $\mathrm{Zn}^{+2}$ and $\mathrm{Cd}^{+2}$, we found growth of some isolates in up to $1.000 \mathrm{mg} \mathrm{L}^{-1} \mathrm{Zn}^{+2}$ and $60 \mathrm{mg}$ $\mathrm{Cd}^{+2} \mathrm{~L}^{-1}$. In our study, $\mathrm{Cd}^{+2}$ was more toxic than $\mathrm{Zn}^{+2}$ to all strains/isolates tested, regardless culture conditions. This is in accordance with other results for rhizobia isolated from both temperate and tropical soils (Angle et al. 1993, Trannin et al. 2001a, Matsuda et al. 2002). Hayat et al. (2002) demonstrated soil populations of asymbiotic bacteria from a soil receiving oil refinery wastewater, as having tolerance to up to $400 \mu \mathrm{g} \mathrm{mL}^{-1}$ (mg L ${ }^{-1}$ ) of both $\mathrm{Cd}$ and $\mathrm{Zn}$, within the range found for
Zn but not for Cd, in our study, as well as by Angle et al. (1993), Trannin et al. (2001a) and Matsuda et al. (2002) when studying rhizobia.

It is well known that plants using Nitrogen from symbiosis with rhizobia are less tolerant to various stress than when they utilize combined Nitrogen (Trannin et al. 2001b). This was the case of all $A$. amazonense strains and isolates, and $A$. brasilense strain 1R, however the other isolates/strains behaved in an opposite way. Further studies are necessary to explore this potential when these organisms are associated with plants.

The large variation observed for $\mathrm{NaCl}$ tolerance of isolates and type strains indicated that this analysis allowed discrimination of these bacteria against abiotic stress. Thirteen out of the fourteen isolates/strains grew at concentration higher than $2 \% \mathrm{NaCl}$, and could be considered facultative halophytes, a commonly found soil bacterial behavior. This observation also corroborated results obtained by Sanches (2002), who utilized different saline concentrations for characterizations of indigenous rhizobia strains, and those from Nóbrega et al. (2004) who also found a large variation in $\mathrm{NaCl}$ tolerance of 72 isolates of diazotrophic associative from bauxite mine spoils. Isolates more tolerant to $\mathrm{NaCl}$ were, 
in general, the most tolerant to HM, showing a relationship between tolerance to $\mathrm{HM}$ and to $\mathrm{NaCl}$.

Bacterial diversity is a source of valuable genetic resources for biotechnology and microbiologists have just begun to access the complexity and the potentialities of tropical diversity. The existence of associative diazotrophic bacteria in disturbed areas such as heavy metal contaminated sites, can indicate that even under adverse soil conditions these organisms can survive and establish associations with plants. Thus, tolerance of some associative diazotrophic isolates to heavy metals can be utilized for further studies, aiming rehabilitation of these sites, by improving functionality and sustainability of ecosystems. On the other hand, diazotrophic populations presenting low tolerance, can be used as quality indicators.

Species identification of UFLA 1S and S181 based on $16 \mathrm{~S}$ rDNA sequencing confirmed previous identification based on cultural characteristics described by Magalhães and Döbereiner (1984) and Döbereiner et al. (1995), i.e, their $16 \mathrm{~S}$ rDNA sequences revealed they are really closest related to A lipoferum and A. brasilense. However, these two isolates are similar to these species at $95 \%$ and $98 \%$, respectively. Similarity of $97 \%$ is usually considered the boundary for species differentiation (Rosseló-Mora and Amann 2001). However, these authors also reported that different species can have identical or nearly identical $16 \mathrm{~S}$ rDNA sequences. Furthermore, protein profiles of isolates UFLA S181 and 1S have a dissimilarity equal or more than $75 \%$ with other Azospirillum type strains, including A. lipoferum and A. brasilense. Many studies have shown different species of different genera as having protein profiles at levels below 80\% (Moreira et al. 1993, De Lajudie et al. 1994) and that, protein profiles similarity highly correlated with DNA homology, i.e, strains with highly similar protein profiles share high DNA hybridization values and therefore belong to the same species (Vandamme et al. 1996). Thus, further studies could indicate if these isolates do belong to these species, or if they are sub-species or new species of this genus.

\section{ACKNOWLEDGMENTS}

To Fundação de Amparo à Pesquisa do Estado de Minas Gerais (FAPEMIG), Coordenação de Aperfeiçoamento de Pessoal de Nível Superior (CAPES) and Conselho Nacional de Desenvolvimento Científico e Tecnológico (CNPq) for students fellowships, to CNPq for research fellowship and grant, and to FAPEMIG and Companhia Mineira de Metais (CMM) for financial support.

\section{RESUMO}

Objetivou-se avaliar a densidade de populações de bactérias diazotróficas associativas em amostras de solos e de raízes de gramíneas oriundas de sítios contaminados com metais pesados, e caracterizar isolados destas populações através da análise fenotípica (tolerância aos metais pesados zinco e cádmio e à $\mathrm{NaCl}$ in vitro, perfis protéicos), e genotípica (seqüenciamento de 16S rDNA), comparados às estirpes tipo das mesmas espécies. As densidades foram avaliadas nos meios NFb, Fam e LGI, comumente utilizados para culturas de enriquecimento de populações de bactérias diazotróficas associativas. As densidades encontradas em amostras de solo e raiz de sítios contaminados foram semelhantes àquelas relatadas na literatura para solos agrícolas. Isolados de Azospirillum spp. de solos contaminados e estirpes tipo oriundas de solos não contaminados variaram substancialmente com relação à tolerância a $\mathrm{Zn}^{+2} \mathrm{e}$ $\mathrm{Cd}^{+2}$, sendo que $\mathrm{Cd}^{+2}$ mais tóxico que $\mathrm{Zn}^{+2}$. Dentre os isolados mais tolerantes (UFLA 1S, 1R, S181, S34, e S22), alguns (1R, S34 e S22) foram mais tolerantes a metais pesados que rizóbios isolados de solos de áreas tropicais e temperadas. A maioria dos isolados mais tolerantes a metais pesados também foi tolerante ao estresse salino, o que foi indicado por seu crescimento em meio sólido suplementado com $30 \mathrm{~g} \mathrm{~L}^{-1}$ de $\mathrm{NaCl}$ in vitro. Cinco isolados apresentaram alta dissimilaridade em perfis protéicos e o seqüenciamento do gene $16 \mathrm{~S}$ rDNA em dois deles revelou que apresentam novas seqüências de Azospirillum.

Palavras-chave: Azospirillum, zinco, cádmio, contaminantes do solo, bactérias fixadoras de $\mathrm{N}_{2}$.

\section{REFERENCES}

Angle JS, MacGrath SP, Chaudri AM, Chaney RL AND GILLER KE. 1993. Inoculation effects on legumes grown in soil previously treated with sewage sludge. Soil Biol Biochem 25: 575-580.

BALDANI JI AND BALDANI VL. 2005. History on the biological nitrogen fixation research in graminaceous plants: special emphasis on the Brazilian experience. An Acad Bras Cienc 77: 549-579. 
BALDANI VLD AND DÖBEREINER J. 1980. Host-plant specificity in the infection of cereals with Azospirillum spp. Soil Biol Biochem 12: 433-439.

Colpaert JV And Assche JAV. 1992. The effects of cadmium and the cadmium-zinc interaction on the axenic growth of ectomycorrhizal fungi. Plant Soil 145: 237243.

DAHLIN S, WitTER E, MÄrTENSSON A, TURNER A AND B̈̈ÄTH E. 1997. Where's the limit? Changes in the microbiological properties of agricultural soils at low levels of metal contamination. Soil Biol Biochem 29: 1405-1415.

de Lajudie P, Willems A, Pot B, Dewettinck D, Maestrojuan G, Neyra M, Collins MD, DreyFus B, Kersters K and Gillis M. 1994. Polyphasic taxonomy of rhizobia: emendation of the genus Sinorhizobium and description of Sinorhizobium meliloti comb. nov., Sinorhizobium saheli sp. nov., Sinorhizobium teranga sp.nov. Int J Syst Bacteriol 44: 715-733.

DiAs-JÚnior HE, MOREIRA FMS, SiqueIRA JO AND SILVA R. 1998. Metais pesados, densidade e atividade microbiana em solo contaminado por rejeitos de indústria de zinco. R Bras Ci Solo 22: 631-640.

DiLWORTH MJ. 1966. Acetylene reduction by nitrogen-fixing preparations from Clostridium pasteurianum. Biochim Biophys Acta 127: 285-294.

DÖBEREINER J. 1978. Influence of environmental factors on the occurrence of Spirillum lipoferum in soils and roots. Ecol Bull 26: 343-352.

DÖBEREINER J, BALDANi VLD AND BALDANi JI. 1995. Como isolar e identificar bactérias diazotróficas de plantas não-leguminosas. Brasília: EMBRAPA-SPI; Seropédica: EMBRAPA-CNPAB, $60 \mathrm{p}$.

Everitt BS. 1993. Cluster analysis. New York : J. Wiley \& Sons Inc, $170 \mathrm{p}$.

Giller KE, Witter E AND MCGRath SP. 1998. Toxicity of heavy metals to microorganisms and microbial processes in agricultural soils: a review. Soil Biol Biochem 30: 1389-1414.

GOWRI PM AND SRIVASTAVA S. 1996. Encapsulation as a response of Azospirillum brasilense sp 7 to zinc stress. World J Microb Biot 12: 319-322.

Hayat S, Ahamad I, AZAm ZM AND InAm A. 2002. Effect of long-term application of oil refinary wasterwater on soil health with special reference to microbiological characteristics. Bioresour Technol 84: 159-163.

Hirsch PR, JONES MJ, MCGRATH SP AND GiLler KE. 1993. Heavy metals from past applications of sawage slud decrease the genetic diversity of Rhizobium leguminosarum biovar trifolii populations. Soil Biol Biochem 25: $1485-1490$.

Kiredjian M, Holmes B, Kersters K, Guilvout J AND DE LEY J. 1986. Alcaligenes piechaudii, a new species from human clinical specimens and the environment. Int J Syst Bacteriol 36: 282-287.

Klauberg-Filho O, Siqueira JO AND Moreira FMS. 2002. Fungos micorrízicos arbusculares em solos de áreas poluídas com metais pesados. $\mathrm{R}$ Bras Ci Solo 26: $125-134$.

LAEMMLI UK. 1970. Cleavage of structural proteins during assembly of the head of bacteriophage Y4. Nature 227: $680-685$.

Lorenz SE, McGrath SP AND Giller KE. 1992. Assessment of free-living nitrogen fixation activity as a biological indicator of heavy metal toxicity in soil. Soil Biol Biochem 4: 601-606.

MAGAlHÃEs FMM AND DÖBEREINER J. 1984 Occurrence of Azospirillum amazonense in some Amazonian ecosystems. Rev Microbiol 15: 246-252.

Magalhães FMM, PATriquin D AND DöBereiner J. 1979. Infection of field grown mayze with Azospirillum spp. Rev Bras Microbiol 39: 587-596.

MARques TClLM, Moreira FMS ANd Siqueira JO. 2000. Growth and metal concentration of seedlings of wood species in a heavy metal contaminated soil. Pesqui Agropecu Bras 35: 121-132.

Matsuda A, Moreira FMS and Siqueira JO. 2002. Tolerance of rhizobia genera from different origins to zinc, copper and cadmium. Pesqu Agropecu Bras 37: 343-355.

Moreira FMS, Gillis M, Pot B, Kersters K AND FRANCO AA. 1993. Characterization of rhizobia isolated from different divergence groups of tropical Leguminosae by comparative polyacrilamide gel eletrophoresis of their total proteins. Syst Appl Microbiol 16: 135-146.

Nóbrega RSA, Moreira FMS, Siqueira JO and Lima AS. 2004. Caracterização fenotípica e diversidade de bactérias diazotróficas associativas isoladas de solos em reabilitação após a mineração de bauxita. R Bras Ci Solo 28: 269-279.

ROHLF FJ. 2002. NTSYSpc: Numerical Taxonomy System, ver. 2.1. Setauket, New York: Exeter Publishing, Ltd.

Rosseló-Mora R And Ammann R. 2001. The species concept for prokaryotes. FMS Microbiol Rev 25: 39-67.

SANCHES AC. 2002. Adubação fosfatada e inoculação de leguminosas com Bradyrhizobim na recuperação de solo 
degradado pela mineração de cassiterita na região amazônica. Universidade Estadual Paulista. (Tese de doutorado) $96 \mathrm{p}$.

Santos PEL, Cristales RB ANd Mellado JC. 2001. Burkholderia, a genus rich in plant-associated nitrogen fixer with wide environmental geographic distribution. Appl Environ Microb 67: 2790-2798.

Strzelczyk E, Pokojska-Burdziej A AND Li CY. 1997. Effect of $\mathrm{Cd}^{+2}, \mathrm{Zn}^{+2}$ and $\mathrm{Cu}^{+2}$ on auxins production by Azospirillum strains. Acta Microbiol Pol 46: 263-270.

Tortora GJ, Funke BR And CAse CL. 2000. Microbiologia. $6^{\mathrm{a}}$ ed. Porto Alegre: Artmed.

TRANNIN ICB, MOREIRA FMS AND SIQUEIRA JO. 2001a. Tolerance of Bradyrhizobium and Azorhizobium strains and isolates to copper, cadmium and zinc in vitro. $\mathrm{R}$ Bras Ci Solo 25: 305-316.
TranNin ICB, Moreira FMS And Siqueira JO. $2001 \mathrm{~b}$. Crescimento e nodulação de Acácia mangium, Enterolobium contortsiliquum e Sesbania virgata em solo contaminado com metais pesados. R Bras Ci Solo 25: 743-753.

TYLER G. 1981. Heavy metals in soil biology and biochemistry. In: PAUL EA AND LADD (Eds), Soil Biochemistry. New York: Marcel Dekker, Inc., p. 371-414.

Vandamme P, Pot B, Gillis M, De Vos P, Kersters K AND SwIngs J. 1996. Polyphasic taxonomy, a consensus approach to bacterial systematics. Microbiol Rev 60: 407-438. 